Pacific Journal of Mathematic 


\title{
HAUSDORFF MEASURE, BMO, AND ANALYTIC FUNCTIONS
}

\section{ROBERT KAUFMAN}

\begin{abstract}
Besicovitch's theorem on removable singularities is extended to function of class BMO. The extende $d$ theorem admits a converse.
\end{abstract}

Let $W$ be an open set in the plane, and the class $\mathrm{BMO}(W)$ be defined as follows: a measurable function $f$ on $W$ is BMO if to each ball $B$ contained in $W$ there is a constant $c=c(B)$ so that $\iint_{B} \mid f(x, y)$ $c(B) \mid d x d y \leqq A m(B)$, with a constant $A=A(f)$. For any complex function $f$ on $W, S(f)$ is the set of points at which $f$ fails to admit a complex derivative; $S(f)$ in general is neither open nor closed, but is in fact a Borel set.

THEOREM (a). Let $f \in \mathrm{BMO}(W)$ and suppose that $S(f)$ has 1dimensional Hausdorff measure 0 . Then there is a function $f_{1}$, holomorphic on $W$, equal to $f$ on $W-S(f)$.

(b) Let $S$ be a compact set of positive 1-measure. Then there $i s$ a function $g$, analytic off $S$, of class $\mathrm{BMO}\left(R^{2}\right)$ with Taylor. expansion $g(z)=z^{-1}+\cdots$ at infinity.

Proof of (a). This relies on Theorem 1 of [3] and the following variant form of Vitali's covering theorem: if a sequence of open balls $\left(B\left(a_{i}, r_{i}\right)\right)_{1}^{\infty}$ covers a bounded set $E$, then it contains a disjoint collection $\left(B\left(a_{j}, r_{j}\right)\right)_{1}^{\infty}$ such that $\mathrm{U}_{j} B\left(a_{j}, 3 r_{j}\right)$ covers $E$. Let $V$ be a bounded subset of $W$ and $\varepsilon>0$; we construct coverings of $V \cap S(f)$ and $V-S(f)$ separately. Inasmuch as $S(f)$ has 1-measure 0 we can cover it with balls $B\left(a_{i}, r_{i}\right)$ such that $B\left(a_{i}, 2 r_{i}\right) \subseteq W$ and $\sum r_{i}<$ $\varepsilon$. For each point $z$ in $V-S(f)$ we can find a number $r(z)>0$ so that $B(z, 6 r(z)) \subseteq W$ and $\left|f(w)-f(z)-(z-w) f^{\prime}(z)\right|<\epsilon r(z)$ when $w \in B(z, 6 r(z))$. The collection $B(z, r(z))$ contains a disjoint sequence $B\left(z_{j}, r\left(z_{j}\right)\right)$ such that $\cup B\left(z_{j}, 3 \pi\left(z_{j}\right)\right) \supseteqq V-S(f)$; by the disjointness, $\sum 9 \pi \lambda^{2}\left(z_{j}\right) \leqq 9 m(V)$. Using the fact that constants are analytic, we see that the conditions of $\left[3, \mathrm{p}\right.$. 108] are fulfilled, so that $f=f_{1}$ a.e., for some function $f_{1}$ holomorphic on $W$. Then $f-f_{1}$ is differentiable on $S-S(f)$, and so $f=f_{1}$ there.

An easy improvement can be obtained from [3], namely, the constant $c(B)$ in the definition of $\mathrm{BMO}(W)$ can be replaced by a polynomial (depending on $B$ ).

Proof of (b). By a theorem of Frostman [2, p. 7], $S$ carries a 
probability measure $\mu$, such that $\mu(B(z, r)) \leqq c r$ for every ball $B$ of radius $r>0$. Let

$$
g(z)=\int(z-\zeta)^{-1} \mu(d \zeta)
$$

so that $g$ is analytic off $S$ and $g(z)=z^{-1}+\cdots$. To prove that $g \in$ BMO $\left(R^{2}\right)$ we choose a ball $B=B(w, r)$, set $B^{*}=B(w, 2 r)$ and $C=$ $R^{2}-B^{*}$. Let

$$
\begin{aligned}
& g_{1}(z)=\iint_{B *}(z-\zeta)^{-1} \mu(d \zeta) \\
& g_{2}(z)=g(z)-g_{1}(z)
\end{aligned}
$$

Now

$$
\begin{aligned}
\iint_{B}\left|g_{1}(z)\right| d x d y & \leqq \mu\left(B^{*}\right) \sup \iint_{B}|z-\zeta|^{-1} d x d y \\
& =2 \pi r \mu\left(B^{*}\right) \leqq 4 \pi c r^{2}
\end{aligned}
$$

Further

$$
\iint_{B}\left|g_{2}(z)-g_{2}(w)\right| d x d y \leqq \int_{C} \int_{B}\left|(z-\zeta)^{-1}-(w-\zeta)^{-1}\right| d x d y \mu(d \zeta) .
$$

From the inequality $|\zeta-w|>2 v(\zeta \in C)$, we find that the inner integral doesn't exceed $(4 \pi / 3) \cdot r^{3}|\zeta-w|^{-2}$, and the entire integral is at most

$$
\begin{aligned}
& (4 \pi / 3) \cdot r^{3} \int_{C}|w-\zeta|^{-2} \mu(d \zeta) \\
& \quad \leqq(4 \pi / 3) \cdot r^{3} c(2 r)^{-1}=2 \pi / 3 \cdot c r^{2}
\end{aligned}
$$

Hence

$$
\iint_{B}\left|g(z)-g_{2}(w)\right| d x d y \leqq 3 c m(B)
$$

REMARKs. (i ) A Borel set $S$ of positive 1-dimensional measure contains a compact set $S_{0}$ of the same kind (Besicovitch) [2, p. 11].

(ii) Besicovitch proved (a) for bounded functions; for continuous $f_{1}$ he proved the sufficiency of the hypothesis that $S(f)$ have $\sigma$-finite 1-dimensional measure. Combining his method for this variant, with the one presented above for $\mathrm{BMO}$, we can replace continuity of $f$ by VMO (vanishing mean oscillation), that is $\iint_{B}|f(x, y)-c(B)| d x d y \leqq m(B) \varepsilon(m(B))$, where $\varepsilon(0+)=0$.

(iii) The variant just mentioned also admits a converse; to explain this we observe that if the probability measure $\mu$ figuring in the proof of (b) has the stronger property that $\mu(B(z, r)) \leqq$ $r \varepsilon(r)$ with $\varepsilon(0+)=0$, then the function $g$ is $\operatorname{VMO}\left(R^{2}\right)$. We use the 
following theorem [4]; a Borel set $S$, not of $\sigma$-finite 1-dimensional measure, contains a compact set $S_{0}$, with positive Hausdorff measure for a measure function $h(u)=u \varepsilon(u)$; by Frostman's theorem $S_{0}$ then carries a probability measure $\mu$ with the stronger property needed to improve VMO to BMO.

\section{REFERENCES}

1. A. Besicovitch, On sufficient conditions for a function to be analytic, Proc. London Math. Soc., 2 (32) (1931), 1-9.

2. L. Carleson, Selected Problems on Exceptional Sets, Van Nostrand, 1967.

3. R. Kaufman and J.-M. Wu, Removable singularities for analytic or subharmonic functions, Arkiv for Mat., 18 (1980), 107-116.

4. M. Sion and D. Sjerve, Approximation properties of measures generated by continuous set functions, Mathematika, 9 (1962), 145-156.

Received August 3, 1981.

UNIVERSITY OF ILLINOIS

URBANA, IL 61801 



\section{PACIFIC JOURNAL OF MATHEMATICS}

\section{EDITORS}

DONALD BABBITT (Managing Editor)

University of California

Los Angeles, CA 90024

Hugo RossI

University of Utah

Salt Lake City, UT 84112

C. C. MOORE and ARThur Agus

University of California

Berkeley, CA 94720
J. DugundJI

Department of Mathematics

University of Southern California

Los Angeles, CA 90007

R. FINN and J. MILGRAM

Stanford University

Stanford, CA 94305

\section{ASSOCIATE EDITORS}
R. ARENS
E. F. BeCKENBACH
B. H. NeumanN
F. WOLF
K. YoSHIDA

\section{SUPPORTING INSTITUTIONS}

UNIVERSITY OF ARIZONA

UNIVERSITY OF BRITISH COLUMBIA

CALIFORNIA INSTITUTE OF TECHNOLOGY

UNIVERSITY OF CALIFORNIA

MONTANA STATE UNIVERSITY

UNIVERSITY OF NEVADA, RENO

NEW MEXICO STATE UNIVERSITY

OREGON STATE UNIVERSITY

\author{
UNIVERSITY OF OREGON \\ UNIVERSITY OF SOUTHERN CALIFORNIA \\ STANFORD UNIVERSITY \\ UNIVERSITY OF AAWAII \\ UNIVERSITY OF TOKYO \\ UNIVERSITY OF UTAH \\ WASHINGTON STATE UNIVERSITY \\ UNIVERSITY OF WASHINGTON
}

The Supporting Institutions listed above contribute to the cost of publication of this Journal, but they are not owners or publishers and have no responsibility for its content or policies,

Mathematical parers intended for publication in the Pacific Journal of Mathematics should be in typed form or offset-reproduced, (not dittoed), double spaced with large margins. Please do not use built up fractions in the text of the manuscript. However, you may use them in the displayed equations. Underline Greek letters in red, German in green, and script in blue. The first paragraph or two must be capable of being used separately as a synopsis of the entire paper. Please propose a heading for the odd unmbered pages of less than 35 characters. Manuscripts, in triplicate, may be sent to any one of the editors. Please classify according to the scheme of Math. Reviews, Index to Vol. 39. Supply name and address of author to whom proofs should be sent. All other communications should be addressed to the managing editor, or Elaine Barth, University of California, Los Angeles, California, 90024.

50 reprints to each author are provided free for each article, only if page charges have been substantially paid. Additional copies may be obtained at cost in multiples of 50 .

The Pacific Journal of Mathematics is issued monthly as of January 1966, Regular subscription rate: $\$ 114.00$ a year (6 Vol., 12 issues). Special rate: $\$ 57.00$ a year to individual members of supporting institution.

Subscriptions, orders for numbers issued in the last three calendar years, and changes of address shoud be sent to Pacific Journal of Mathematics, P.O. Box 969, Carmel Valley, CA 93924, U.S.A. Old back numbers obtainable from Kraus Periodicals Co., Route 100, Millwood, NY 10546.

\section{PUBLISHED BY PACIFIC JOURNAL OF MATHEMATICS, A NON-PROFIT CORPORATION}

Printed at Kokusai Bunken Insatsusha (International Academic Printing Co., Ltd.). 8-8, 3-chome, Takadanobaba, Shinjuku-ku, Tokyo 160, Japan. 


\section{Pacific Journal of Mathematics}

\section{Vol. 102, No. 2 \\ February, 1982}

Richard A. Boyce, Irreducible representations of finite groups of Lie type through block theory and special conjugacy classes ...............253

Robert Jay Daverman and Dennis J. Garity, Intrinsically

$(n-2)$-dimensional cellular decompositions of $E^{n} \ldots \ldots \ldots \ldots 275$

Juan Ferrera, Spaces of weakly continuous functions ................285

William George Frederick, $\mu$-theta functions ................... 293

Christopher George Gibson and T. D. Ward, On stratifying pairs of linear

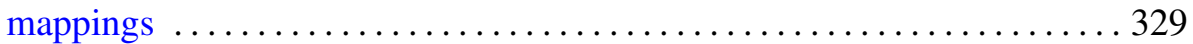

Stanley Joseph Gurak, Minimal polynomials for Gauss circulants and cyclotomic units ........................................ 347

Joachim Georg Hartung, On two-stage minimax problems ............. 355

Robert P. Kaufman, Hausdorff measure, BMO, and analytic functions . . . . 369

Neal I. Koblitz, $p$-adic analog of Heine's hypergeometric $q$-series . . . . . . . 373

Kurt Kreith, Picone-type theorems for hyperbolic partial differential

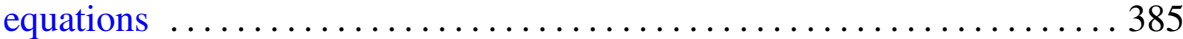

Nicholas J. Kuhn, The geometry of the James-Hopf maps ............. 397

Donald Michael Redmond, Explicit formulae for a class of Dirichlet

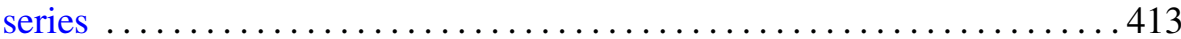

J. R. Respess and Elliott Ward Cheney, Jr., Best approximation problems in tensor-product spaces . .............................. 437

Allen Ross Schweinsberg, The operator equation $A X-X B=C$ with normal $A$ and $B$

Hans-Willi Siegberg and Guentcho Svetoslavov Skordev, Fixed point index and chain approximations

Kondagunta Sundaresan, Geometry and nonlinear analysis in Banach spaces 